\title{
The Implementation of Distance Learning during the Covid-19 Pandemic
}

\section{Implementasi Pembelajaran Jarak Jauh pada Masa Pandemi Covid-19}

\author{
Raden Adji Suryo Utomo', Fitri Nur Mahmudah ${ }^{2}$ \\ 1,2Universitas Ahmad Dahlan, Yogyakarta

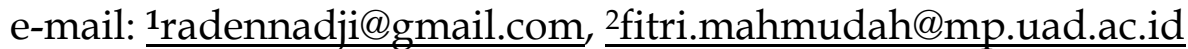

\section{DOI: $10.18860 /$ mad.v13i2.11330}

Abstract. The implementation of learning is the most important part in improving the quality of education. The Covid-19 pandemic period is part of the challenge for education so that learning continues. The purpose of this study was to investigate in depth the implementation of distance learning during the Covid-19 pandemic. The method used in this research is qualitative with a case study approach. The research was conducted at Muhammadiyah Pakel Elementary School. The data sources in this study were teachers, parents, and students. Data collection techniques using structured interviews assisted with guidelines that are structured questions systematically. Data analysis using the Denzin \& Licoln case study model assisted by atlas.ti software version 8 . The technique used to improve the quality of research is source triangulation. The results of this study provide information that in the implementation of the implementation of distance learning there are three factors, namely policy, distance learning process, and human resource activeness. These three factors are novelty which can be recommendations for the three education centers in order to be part of improving the quality of distance learning education during the Covid-19 pandemic.

Keywords. Implementation; Distance Learning; Covid-19 Pandemic

\begin{abstract}
Abstrak. Pelaksanaan pembelajaran menjadi bagian terpenting dalam peningkatan mutu pendidikan. Masa pandemi Covid-19 menjadi bagian tantangan bagi pendidikan supaya pembelajaran tetap berjalan. Tujuan penelitian ini adalah untuk menyelidiki secara mendalam implementasi pembelajaran jarak jauh pada masa pandemi Covid-19. Metode yang digunakan dalam penelitian ini adalah kualitatif dengan pendekatan studi kasus. Penelitian dilakukan di SD Muhammadiyah Pakel. Sumber data dalam penelitian ini adalah guru, orang tua, dan siswa. Teknik pengambilan data dengan menggunakan wawancara terstruktur berbantuan pedoman yang tersusun pertanyaan secara sistematis. Analisis data dengan model studi kasus Denzin \& Licoln berbantuan software atlas.ti versi 8 . Teknik yang digunakan dalam meningkatkan kualitas penelitian adalah trianggulasi sumber. Hasil penelitian ini memberikan informasi bahwa dalam implementasi pelaksanaan pembelajaran jarak jauh terdapat tiga faktor yaitu kebijakan, proses distance learning, dan keaktifan SDM. Ketiga faktor tersebut merupakan novelty yang dapat menjadi rekomendasi untuk tripusat pendidikan dalam rangka menjadi bagian dalam meningkatkan mutu pendidikan pembelajaran jarak jauh selama pandemi Covid-19
\end{abstract}

Kata kunci. Implementasi; Pembelajaran Jarak Jauh; Pandemi Covid-19

Vol. 13 No. 2 Juni 2021 


\section{MADRASAH}

Jurnal Pendidikan dan Pembelajaran Dasar

p ISSN: 1979-5599 | e ISSN: 2502-194X

P a g e | $\mathbf{1 1 5}$

Received: 11-01-2021

Approved: 14-02-2021

Revised: 14-02-2021

Published: 05-04-2021

Copyright (C Madrasah Jurnal Pendidikan dan Pembelajaran Dasar. All Right Reserved. This is an open access article under the CC BY-SA license

(Creative Commons Attribution-ShareAlike 4.0 International License.)

Correspondence Address: fitri.mahmudah@mp.uad.ac.id

\section{A. PENDAHULUAN}

Pandemi Covid-19 yang terjadi, menyebabkan segala aspek kehidupan mengalami perubahan dan penyesuaian. Dampak tersebut terasa khususnya pada kesehatan, ekonomi, dan pendidikan. Hal ini didukung pernyataan Menteri Pendidikan dan Kebudayaan Republik Indonesia, yang menyatakan bahwa di masa pandemi, pemerintah wajib hadir di masyarakat yang mengalami krisis kesehatan, ekonomi, dan pembelajaran. Pernyataan tersebut menegaskan bahwa salah satu dari bidang yang mengalami krisis dimasa pandemi Covid-19 yaitu pembelajaran wajib diutamakan dan diperhatikan oleh pemerintah sebuah negara. Hal tersebut seperti yang disampaikan oleh Abidah et al. (2020: 28) bahwa "the impact of the Corona virus disease 2019 (Covid-19) pandemic is now beginning to spread to the world of education." Oleh karena itu perlunya strategi yang dilakukan supaya pembelajaran tetap berjalan walau kondisi lingkungan tidak memungkinkan untuk pembelajaran tatap muka.

Pembelajaran jarak jauh merupakan salah satu upaya yang menjadi regulasi pemerintah Indonesia selama pandemi Covid-19. Hal ini sesuai dengan kebijakan yang diputuskan oleh Pemerintah Indonesia (2020: 3) mengenai pedoman pelaksanaan kurikulum pada satuan pendidikan dalam kondisi khusus. Kebijakan yang ditetapkan adalah kurikulum darurat selama pandemi virus corona (Covid-19). Implementasi keputusan tersebut tertuang dalam tiga penerapan pembelajaran jarak jauh yaitu secara dalam jaringan (online), luar jaringan (offline), dan pembelajaran tatap muka. Pembelajaran jarak jauh menjadi hal utama yang bisa dilakukan. Hal ini mengantisipasi dan memutus mata rantai penyebaran virus Corona. Guru dan peserta didik melakukan pembelajaran secara online dan jarak jauh dari rumah masing-masing. Ini merupakan kondisi belajar dari rumah yang menjadi solusi terbaik bagi pendidikan supaya proses pembelajaran tetap berjalan.

Pada umumnya pendidikan jarak jauh diidentifikasikan sebagai semua bentuk pembelajaran formal yang diselenggarakan ketika guru dan peserta didik tidak berada di lokasi yang sama. Proses pembelajaran jarak jauh yang mendadak ini membutuhkan persiapan yang cepat juga, "The condition shifted the class from classroom to distance learning" Apriyanti (2020: 16). Sarana yang digunakan bukan lagi ruang kelas melainkan ketersediaan internet dan peralatan yang dibutuhkan, seperti laptop, handphone, , kuota, dan jaringan internet, "learning activities were delivered in full distance learning employing various online meeting platforms" Amir et al. (2020: 7). Kemajuan teknologi menjadi solusi yang tepat untuk pembelajaran jarak jauh dimasa pandemi Covid-19. Hal ini ditegaskan oleh Syakdiyah et al. (2019: 2) bahwa "The rapid development of digital era requires people to be competitive and productive subjects in response to it." Sarana ini dibutuhkan untuk menunjang proses pembelajaran jarak jauh. Internet menjadi prioritas utama untuk

Vol. 13 No. 2 Juni 2021 
menghubungkan materi pembelajaran dari guru kepada para peserta didik dan orang tua di rumah selama Covid-19. Oleh karena itu perlunya kemudahan aksesibilitas kedua belah pihak supaya proses pembelajaran berjalan sesuai yang diharapkan.

Aksesibilitas merupakan tolak ukur bagi guru dan peserta didik yang melakukan pembelajaran jarak jauh. Aksesibilitas menjadi kebutuhan dan sekaligus sebagai kendala. Sari et al. (2020: 5) menyatakan bahwa penggunaan internet/e-learning memiliki kendala yang cukup besar, koneksi jaringan dan kesalahan teknis seperti server down dan error menghambat keberhasilan pembelajaran. Belum lagi masalah terkait dengan pemerataan aksesabilitas, seperti di desa-desa dan atau di wilayah terpencil yang tidak ada akses internet. Hal ini menjadi permasalahan baru yang timbul dalam pembelajaran jarak jauh. Seperti yang disampaikan oleh Suyantiningsih (2003: 5) bahwa "peserta didik menjadi tidak fokus untuk belajar karena bisa akses yang lain ketika memegang HP dalam proses pembelajaran jarak jauh". Begitu juga yang disampaikan oleh Darmawan (2009: 6) bahwa "kurang terampil dalam mengaksses informasi melalui teknologi menjadi kendala dalam proses pembelajaran jarak jauh." Melalui pra survei lingkungan sekitar di SD Muhammadiyah Pakel Yogyakarta juga mengalami kendala yaitu minimnya ketersediaan teknologi yang mendukung, kurangnya kreativitas guru dalam memberikan pembelajaran, kesiapan orang tua dalam mendampingi anak belajar di rumah, dan tekanan ekonomi keluarga. Kendala ini juga dipertegas oleh data survei dari lembaga di Indonesia.

Gambar A.1 Tantangan Pembelajaran Jarak Jauh

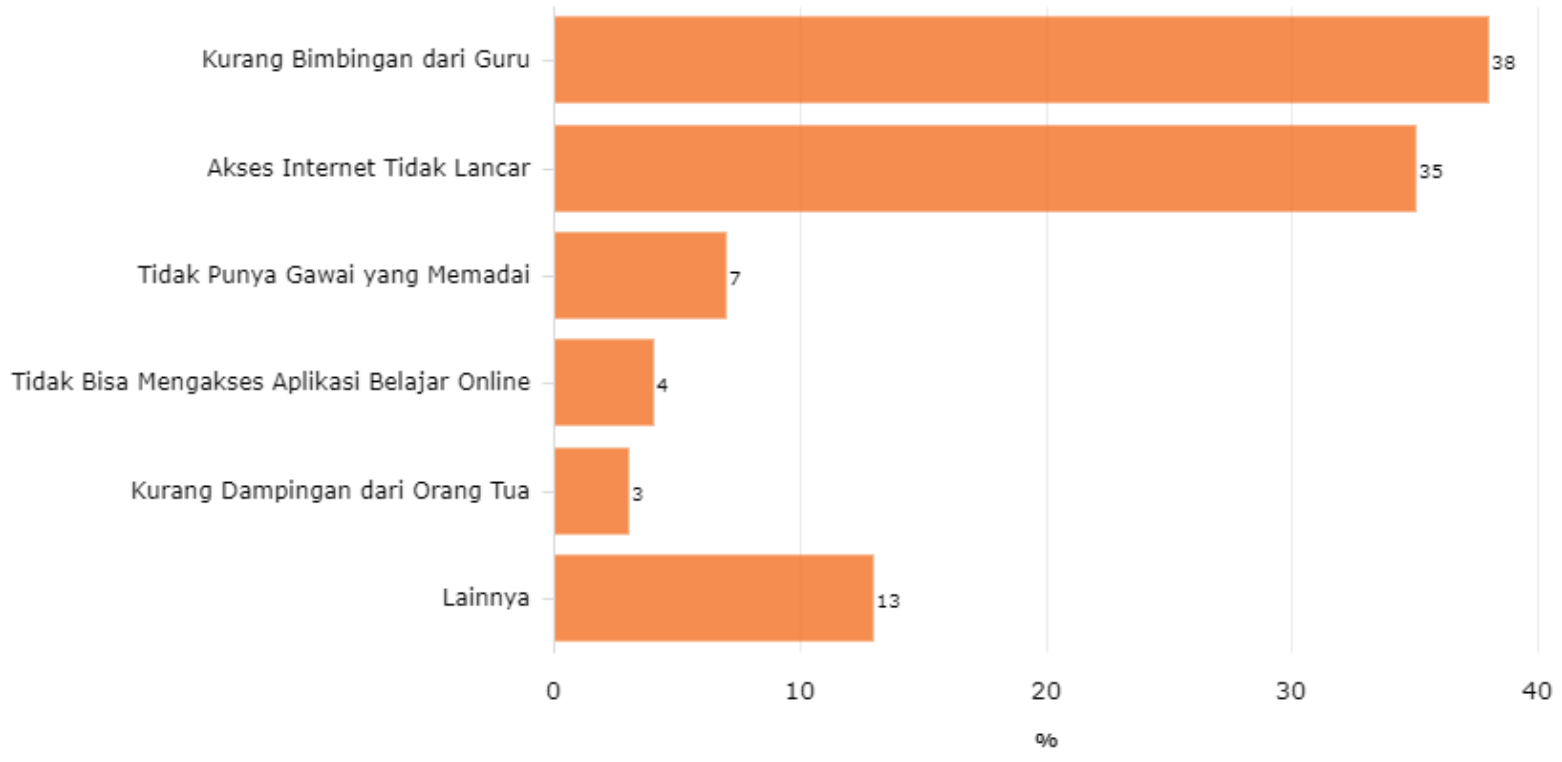

Sumber: U-Report Indonesia, 2020

Data gambar A.1 di atas dapat dimaknai bahwa tantangan tertinggi dalam proses pembelajaran jarak jauh adalah karena kurang bimbingan dari guru yaitu $38 \%$ dan yang paling rendah adalah kurang dampingan dari orang tua sebesar 3\%. Tantangan ini menjadi perhatian utama khususnya pada peserta didik Sekolah Dasar yang notabene masih membutuhkan parental involvement dalam pembelajaran. Pembelajaran jarak jauh yang harus melibatkan orang tua dalam akses materi, mendampingi dalam penyelesaian tugas yang diberikan guru, dan menyampaikan hasil yang sudah dikerjakan peserta didik di rumah kepada guru. Peran penting ini menjadi salah satu pengaruh dalam 


\section{MADRASAH}

Jurnal Pendidikan dan Pembelajaran Dasar

kesuksesan pembelajaran jarak jauh. Tercapaianya misi dan visi dalam pembelajaran jarak jauh menjadi peran bersama, tidak hanya guru melainkan juga keaktifan orang tua dan peserta didik selama pembelajaran di rumah. Daya dukung utama dalam pembelian kuota internet sementara sudah disubsidi oleh pemerintah.

Gambar A.2 Subsidi Kuota Internet dari Kemendikbud

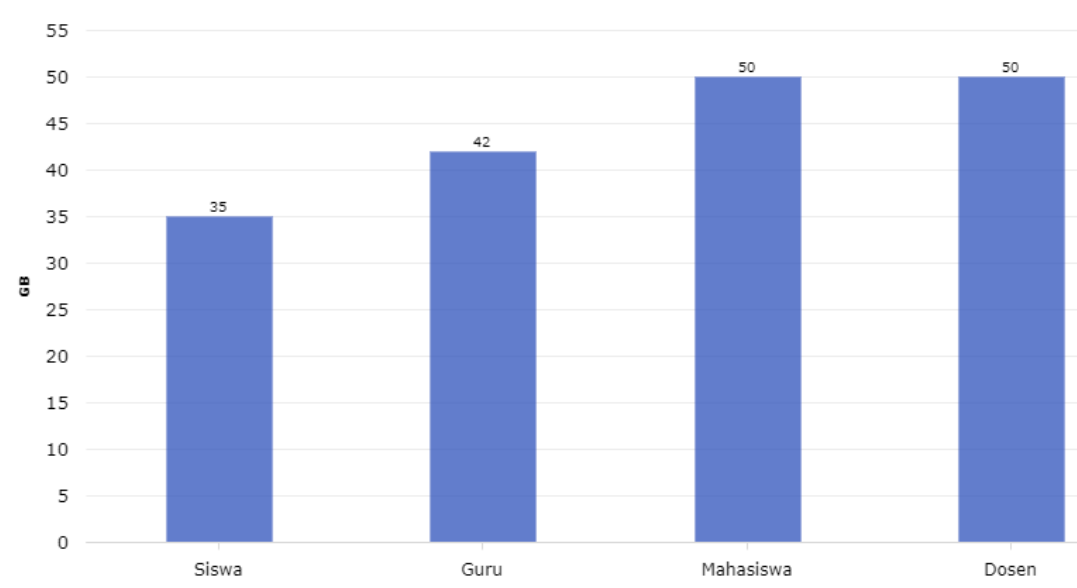

Sumber: Kementerian Pendidikan dan Kebudayaan, 27 Agustus 2020

Data BPS-Statistics Indonesia (2019) pada gambar A.2 di atas dapat dimaknai bahwa kuota yang digunakan dalam pembelajaran jarak jauh untuk peserta didik diberikan sesuai dengan kebutuhan. Peserta didik diberikan gratis kuota oleh pemerintah sesuai dengan porsinya. Artinya terdapat daya dukung pemerintah terhadap kelancarana dalam pelaksanaan pembelajaran jarak jauh selama pandemi Covid-19. Begitu juga terkait sumber listrik dan akses internet dalam pembelajaran. Jenjang Sekolah Dasar (SD) terbanyak di Indonesia sehingga pada saat pembelajaran jarak jauh membutuhkan akses internet yang paling banyak.

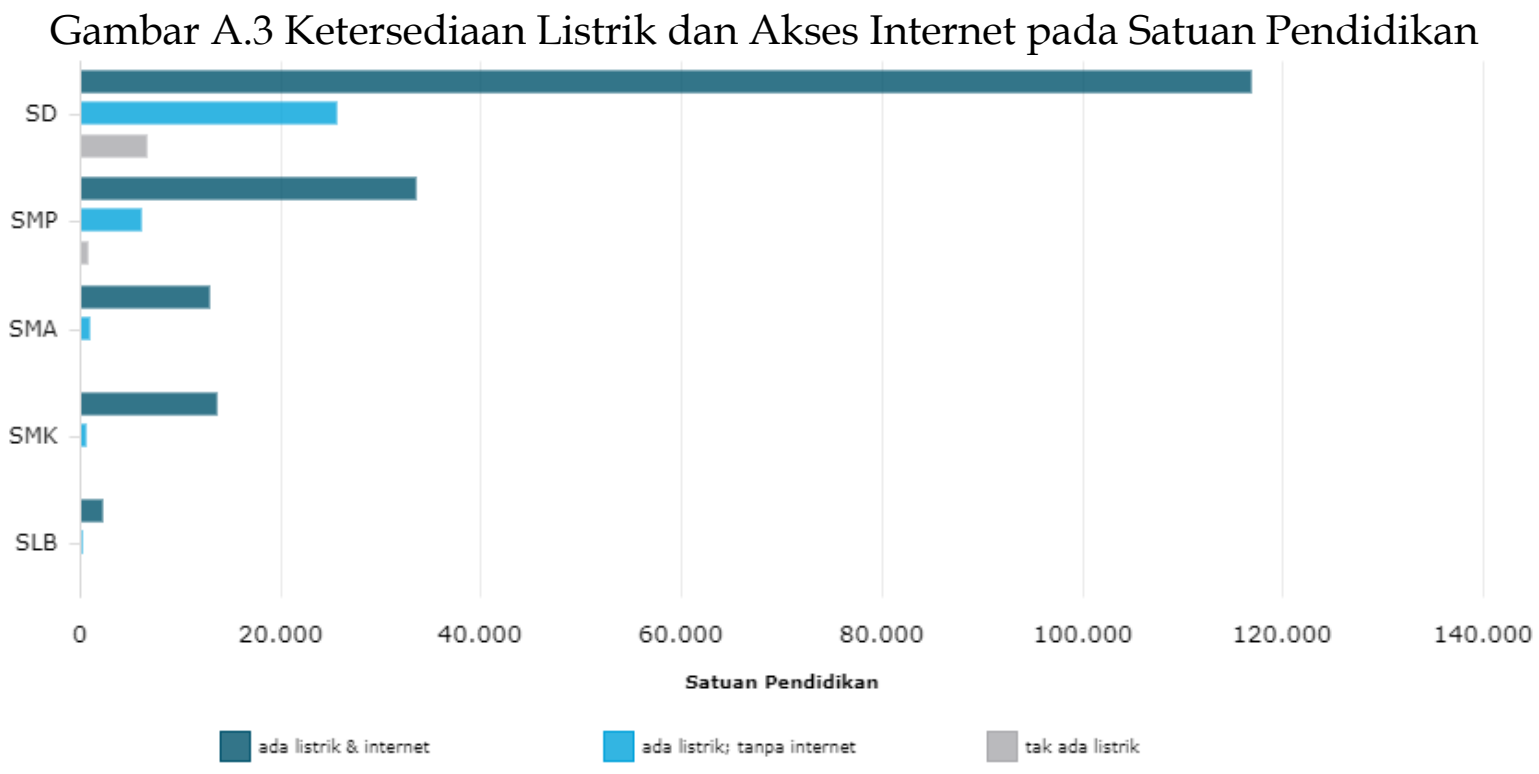

Sumber: Kementerian Pendidikan dan Kebudayaan, 13 April 2020

Vol. 13 No. 2 Juni 2021 
Implementasi pembelajaran jarak jauh bagi para peserta didik menjadi sangat penting karena menyangkut tentang peradaban sebuah negara di masa kini dan masa mendatang. Sahlberg (2020: 3) menyatakan bahwa "the successful education systems perform well in excellence and equity of student's learning outcomes, but many children in the world don't have equal opportunities to good education." Hal tersebut juga ditegaskan oleh Kristanto (2020: 1) bahwa perlunya prinsip 'pengajaran sebagai interaksi' sebagai kerangka dalam mendesain pembelajaran jarak jauh. Hasil penelitian yang telah dilakukan oleh Amir et al. (2020: 2) bahwa despite some challenges, dental students could adapt to the new learning methods of full DL and the majorities agreed blended learning that combined classroom and distance learning can be implemented henceforth. This current COVID-19 pandemic, changes not only the utilization of technology in education but the pedagogy strategies in the future. Begitu juga menurut Abuhammad (2020: 3) dari hasil penelitian yang sudah dilakukan bahwa the study identified a total of 248 posts and threads which categorized thematically for further analysis. The selected threads and answers revealed four underlying themes: (1) personal barriers (2) technical barriers (3) logistical barriers and (4) financial barriers. Tantangan lain juga muncul dari diri siswa pada saat pembelajaran jarak jauh selama di rumah. Hal ini disampaikan oleh Churiyah et al. (2020) dari hasil penelitian yang sudah dilakukan, bahwa students have low self-regulated learning so they are less able to regulate their distance learning activities, teachers tend to stutter about technology, and parents lack understanding of the nature of teaching and learning activities carried out at home. Berbagai tantangan yang ada sehingga pentingnya guru sebagai faktor utama dalam proses pembelajaran jarak jauh mampu mewujudkan pembelajaran yang tidak membosankan bagi para siswa di rumah dengan menggunakan berbagai platforms. Hal ini seperti pernyataan yang disampaikan oleh Rizaldi \& Fatimah (2020) bahwa teachers as an essential factor in the achievement of the learning process, especially during the COVID-19 pandemic, must be able to create and provide usefully and not dull learning conditions, one of which is by trying to use various learning models platforms such as Zoom Cloud Meeting, Google Forms, Jitsi Meet App, Whatsapp Groups and more.

Pernyataan tersebut dapat dimaknai bahwa pendidikan memberikan kesempatan belajar untuk seluruh peserta didik Sekolah Dasar dimanapun berada. Pembelajaran yang dilakukan secara jarak jauh membutuhkan strategi-strategi yang kuat untuk dapat diimplementasikan. Berdasarkan kajian penelitian yang sudah dilakukan oleh para peneliti terdahulu bahwa penelitian ini memberikan kajian yang berbeda. Selama pandemi Covid-19, metode pembelajaran yang digunakan berbeda dengan sebelumnya, sehingga tetap diupayakan peserta didik untuk dapat mengikuti dengan baik, kegiatan pembelajaran online yang efektif, berkualitas, dan berdampak pada output peserta didik yaitu meningkatkan prestasi belajar. Atas dasar itu sehingga pentingnya melakukan penelitian ini. Manfaat praktis yang dapat diperoleh dengan melakukan penelitian terhadap masalah tersebut yaitu meningkatkan kenyaman siswa selama proses belajar jarak jauh, meningkatkan hasil belajar siswa, dan menambah inovasi-kreativitas bagi guru dalam memberikan materi secara jarak jauh. Sedangkan, manfaat teoretis hasil dari penelitian ini diharapkan dapat digunakan sebagai bahan kajian guru untuk meningkatkan kemampuan dan keterampilan serta inovasi dalam pembelajaran. Begitu juga bagi orang tua, untuk dapat meningkatkan involvement kepada para anak di rumah sehingga proses pembelajaran jarak jauh dapat berjalan sesuai dengan harapan. Novelty yang didapatkan dari penelitian ini adalah gambaran secara mendalam terkait

Vol. 13 No. 2 Juni 2021 


\section{MADRASAH}

Jurnal Pendidikan dan Pembelajaran Dasar

p ISSN: 1979-5599 | e ISSN: 2502-194X

implementasi pelaksanaan pembelajaran jarak jauh untuk peserta didik Sekolah Dasar selama pandemi Covid-19. Rumusan masalah dalam penelitian ini adalah bagaimana implementasi pembelajaran jarak jauh untuk siswa SD selama pandemi Covid-19? Atas dasar rumusan masalah tersebut sehingga tujuan dari penelitian ini adalah untuk mengetahui pelaksanaannya sehingga memberikan manfaat kepada guru, orang tua, dan peserta didik Sekolah Dasar.

\section{B. METODE PENELITIAN}

Metode yang digunakan dalam penelitian ini adalah kualitatif dengan jenis penelitian studi kasus. Alasan menggunakan studi kasus adalah untuk menyelidiki secara mendalam dan cermat terkait dengan proses pembelajaran jarak jauh selama masa pandemi Covid-19. Seperti yang disampaikan oleh Stake (2010: 18) bahwa "case study researchers to create reports that provide grounds for and stimulate action." Kasus yang dikaji dibatasi waktu yaitu pada bulan Oktober 2020. Peneliti mengumpulkan informasi secara lengkap dengan menggunakan teknik wawancara dengan pendekatan terstruktur dan dilakukan dengan menggunakan pedoman wawancara. Research setting dalam penelitian ini adalah SD Muhammadiyah Pakel, Yogyakarta. Alasan memilih lokasi penelitian dikarenakan secara demografi tempat ini mudah dijangkau peneliti untuk dijadikan sebagai objek penelitian. Sumber data adalah orang tua, siswa, dan guru total sebanyak tiga orang. Alasan pemilihan sumber data dalam penelitian ini adalah karena orang tua, siswa, dan guru menjadi kunci utama dalam pendidikan dan keberhasilan proses pembelajaran yang berlangsung sekalipun jarak jauh. Pengambilan data dilakukan secara terus menerus dan mendalam sekaligus untuk menjamin kualitas dari data ini. Hal ini menggunakan trianggulasi sumber. Analisis data dalam penelitian ini menggunakan model studi kasus Denzin \& Lincoln (2018: 13) dengan berbantuan software Atlas.ti versi 8.

Prosedur Denzin \& Lincoln (2018: 13) yang digunakan dalam penelitian ini dijabarkan secara mendetail sebagai berikut:

1. Konseptulisasi objek penelitian dalam penelitian ini dilakukan dengan cara membingkai kasus dan menentukan kasus terkait dengan proses pelaksanaan pembelajaran jarak jauh selama pandemi Covid-19 bagi untuk guru, orang tua, dan siswa dan di sekolah maupun di rumah secara komprehensif.

2. Menentukan tema dalam penelitian ini dilakukan dengan cara memilih fenomena yang menjadi fokus dari penelitian yaitu fenomena-fenomena yang terdapat di latar bekalang masalah mengenai data-data jumlah Sekolah Dasar di Indonesia, tantangan atau kendala dalam pelaksanaan proses pembelajaran jarak jauh, dan sarana yang digunakan dan mendukung dalam proses pembelajaran.

3. Melacak pola data dalam penelitian ini digunakan untuk memperkaya isu-isu mengenai pembelajaran jarak jauh selama pandemi Covid-19. Pola-pola data dilakukan setelah data-data terkumpul dengan menggunakan teknik wawancara.

4. Validasi proses yang dilakukan dalam penelitian ini dengan menggunakan trianggulasi sumber

5. Penafsiran dilakukan secara keseluruhan setelah data sudah dianalisis dengan menggunakan bantuan software Atlas.ti

Vol. 13 No. 2 Juni 2021 
6. Akhir dari penelitian ini adalah generalisasi yaitu dengan cara membuat peta konsep penelitian mengenai implementasi pembelajaran jarak jauh di Sekolah Dasar selama pandemi Covid-19.

Analisis data dilakukan dengan cara membuat transkrip pada data-data yang dikumpulkan melalui wawancara. Hasil rekaman yang sudah ditranskrip kemudian diinput ke dalam software Atlas.ti versi 8.3. Selanjutnya melakukan penamaan data-data tersebut untuk memastikan relevansi dari penelitian ini. Data-data yang sudah diberi nama kode ini menjadi dasar untuk membuat peta konsep penelitian ini. Peta konsep dilakukan dengan cara menggabungkan kode-kode yang sama dengan memberikan nama yang relevan dengan penelitian ini.

\section{HASIL DAN PEMBAHASAN}

Analisis data dilakukan secara sistematis dari hasil pengambila data lapangan dengan menggunakan wawancara. Data dalam penelitian ini diorganisasikan secara verbatim sesuai dengan jawaban-jawaban para nara sumber yang telah tersusun dalam pedoman wawancara. Selanjutnya dianalisis dengan mereduksi data-data yang tidak relevan dengan kajian untuk membuat kode-kode dari penelitian. Kode-kode yang sudah didapatkan dari transkrip data selanjutnya dibuat kategorisasi untuk memudahkan peneliti menentukan peta konsep penelitian ini. Analisis data dilakukan selama proses penelitian berlangsung. Berikut hasil analisis data yang telah dilakukan dengan berbantuan software atlas.ti versi 8 .

\section{Gambar A.4 Hasil Analisis Data Penelitian Penelitian Distance Learning}

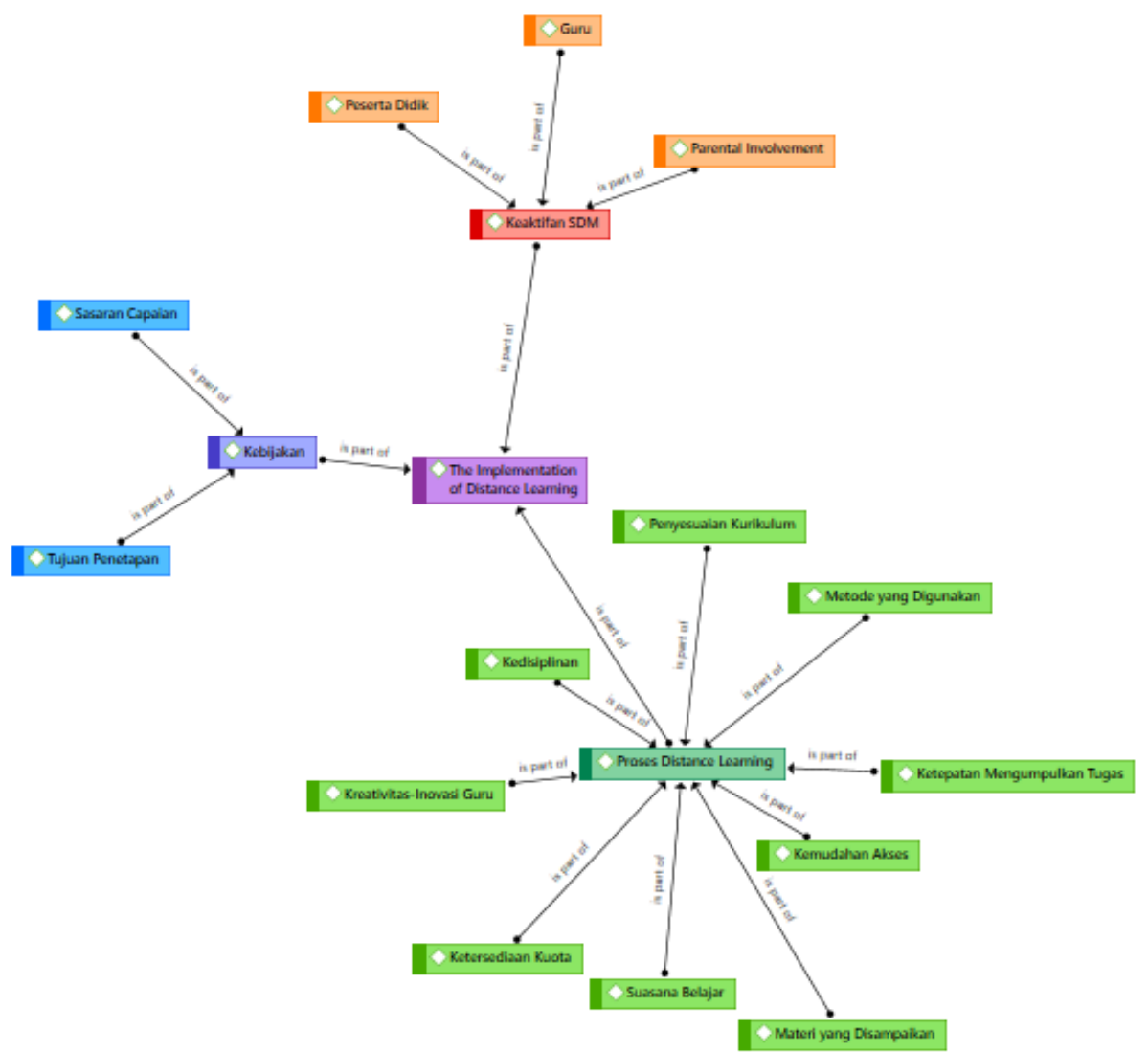

Sumber: Data yang diolah menggunakan software Atlas.ti versi 8

Vol. 13 No. 2 Juni 2021 
Gambar A.4 di atas merupakan hasil analisis data dalam penelitian mengenai implementasi pembelajaran jarak jauh yang ada di SD Muhammadiyah Pakel, Yogyakarta. Temuan dari analisis data memberikan informasi bahwa dalam implementasi pembelajaran jarak jauh selama pandemi Covid-19 memiliki tiga unsur penting yaitu adanya kebijakan, keaktifan SDM, dan proses pembelajaran. Ketiga hal tersebut menjadi satu kesatuan dalam kelancaran proses pembelajaran jarak jauh. Tiga faktor temuan dari penelitian ini masih memiliki indikator-indikator yang perlu diperhatikan bersama untuk dapat memanfaatkan situasi, sumber daya, dan kemampuan yang ada dalam menunjang pelaksanaan pembelajaran.

Pembelajaran Jarak Jauh pada Masa Pandemi Covid-19 yang dilaksanakan di SD Muhammadiyah Pakel memadukan antara dalam jaringan (daring/online) dan luar jaringan (luring/offline). Pada pembelajaran online, guru dapat membuat video membelajaran kemudian dibagikan melalui kanal YouTube atau melalui Whatsapp Group. Guru juga dapat menggunakan beberapa jenis media video call seperti Whatsapp, Zoom, dan Google Meet. Penentuan penggunaan media ini berdasarkan kesepakatan bersama antara guru dengan orang tua. Adapun teknis video call yang dilaksanakan adalah dengan 1) video call klasikal, yakni setiap kelas memiliki kesempatan minimal 1 jam mendapat penjelasan materi dari guru setiap 1 pekan sekali, lalu 2) videocall kelompok, yakni setiap kelas dibagi menjadi beberapa kelompok kecil dimana setiap kelompok mendapat kesempatan durasi 1 jam setiap 1 pekan sekali, serta 3) videocall umum, yakni menggabungkan 3 kelas dalam 1 rombel untuk mendapatkan penjelasan dari guru mata pelajaran dari non wali kelas dengan durasi 1 jam setiap pekan sekali. Sedangkan pada pembelajaran offline, siswa menyerahkan buku tulis berisi tugas yang telah tuntas selama sepekan untuk dikumpulkan dan dikoreksi oleh guru setiap 1 pekan sekali.

Pembelajaran jarak jauh terjadi dikarenakan sebuah sebab, yakni adanya wabah pandemi global Covid-19. Kebijakan ini dilakukan sebagai upaya pencegahan penularan virus tersebut di sekolah-sekolah. Penelitian yang sudah dilakukan memberikan indikator informasi dari kebijakan implementasi pembelajaran jarak jauh yaitu dua hal tujuan penetapan dan sasaran capaian. Penetapan kebijakan tentunya didasarkan pada rumusan analisis kebutuhan guna untuk menyelesaikan masalah. Solusi yang diberikan sebagai alternatif untuk tetap bertahan dan melaksanakan proses pembelajaran walau kondisi tidak memungkinkan. Menurut Ramdhani \& Ramdhani (2017: 3) menyatakan bahwa "kebijakan publik ditetapkan oleh para pihak (stakeholders), terutama pemerintah yang diorientasikan pada pemenuhan kebutuhan dan kepentingan masyarakat". Begitu juga yang disampaikan oleh Mesiono (2010: 2) bahwa “....tujuan seperti menjamin bahwa setiap murid dapat mencapai tingkat tinggi kemampuan membaca pada semua usia murid dan dalam berbagai keadaan". Begitu juga halnya sasaran capaian, ini dimaksudkan untuk "membentuk pola baru mengenai operasional kebijakan (Suyahman (2016: 4)".

Pada saat kebijakan sudah ditetapkan, pelaksanaan pembelajaran jarak jauh memiliki konsekuensi bagi siswa, guru, maupun orang tua sebagai sasaran. Sebagai guru, materi dan tugas yang disampaikan harus mampu dikemas secara menarik dan

Vol. 13 No. 2 Juni 2021 
lebih kreatif sehingga dapat diterima siswa dan dibantu oleh orang tua yang mendampinginya. Di SD Muhammadiyah Pakel, guru sebagai pendidik telah berusaha dalam hal persiapan, penyampaian, hingga evaluasi belajar. Hal ini dibuktikan dengan adanya produksi video sendiri oleh guru, sehingga siswa benar-benar mendapatkan materi yang riil dari gurunya. Selain video pembelajaran, adapula kegiatan video call yang memanfaatkan teknologi sebagai media pembelajaran. Sedangkan siswa sebagai penerima materi, materi tersebut harus mampu dipelajari dengan maksimal meskipun banyak keterbatasan baik dari segi kuota, kejelasan guru yang memberikan pembelajaran, dan dukungan orang tua. Sebagai orang tua, harus mau dan mampu mengelola waktu, tenaga, pikiran, emosi, dan biaya dalam mendampingi siswa belajar dari rumah. Hal ini sesuai dengan hasil penelitian yaitu mengenai keaktifan SDM dengan indikator guru, orang tua, dan siswa. Ketiga pusat pendidikan tersebut menjadi hal penting yang harus diinvestasikan. Seperti yang disampaikan oleh Mahmudah \& Cahya (2020: 3) bahwa "Investing in human resources is one of the ways to cultivate knowledge, skills, and attitudes". Oleh karena itu perlunya kontribusi aktif dalam proses pembelajaran jarak jauh.

Proses pembelajaran jarak jauh memiliki karakteristik yang berbeda dengan pembelajaran secara tatap muka. Hal ini membutuhkan effort untuk dapat melihat hasil akhir dari prosesnya. Tujuan utama masih sama yaitu untuk meningkatkan prestasi belajar dan secara kolektif dapat meningkatkan mutu pendidikan. Di SD Muhammadiyah Pakel, ditemukan keluhan siswa yang sudah jenuh belajar di rumah, mereka ingin segera belajar di sekolah. Anak-anak berpendapat, belajar di sekolah lebih menyenangkan karena dapat bertemu teman-teman dan guru, sehingga selain belajar juga dapat bermain bersama. Selain itu, orang tua juga mengeluhkan kendala berupa kesehatan mata anak yang terlalu sering bersinggungan dengan gadget. Hal ini berdampak pada terjadinya ketergantungan terhadap gadget.

Keluhan lainnya adalah tidak ada subsidi kuota yang kontinyu, sehingga orang tua harus menanggung beban kuota internet disamping membayar SPP sekolah. Keluhan yang juga dirasakan adalah soal waktu yang terbatas untuk siswa mendapatkan penjelasan materi dari guru, karena hanya melalui videocall yang terbatas dalam durasi 1 jam, serta video pembelajaran yang berdurasi 5-10 menit saja. Berdasarkan hasil analisis pada gambar A.4 diketahui bahwa indikator dari proses pembelajaran adalah penyesuaian kurikulum, metode yang digunakan, ketepatan mengumpulkan tugas, materi yang disampaikan, suasana belajar, ketersediaan kuota, kreativitas-inovasi guru, dan kedisiplinan. Temuan tersebut senada dengan penelitian yang pernah dilakukan Rahmawati (2009: 4) bahwa "kendala utama yang dihadapi dalam pembelajaran jarak jauh ada masalah internet". Begitu juga Akther (2016: 5) bahwa "one of the impact of distance learning is interaction of student and learning materials". Hasil penelitian yang telah dilakukan oleh Ngyen (2017: 6) bahwa "the impact of interactive form to student performance based on previous studies have shown these types of interactions mentioned above can affect the student learning outcomes". Dampak dalam pembelajaran jarak jauh merupakan pengaruh yang dapat dilihat dan dirasakan oleh siswa, guru, dan orang tua secara langsung dan kontinyu selama pandemi Covid-19.

Kompleksitas permasalah proses pelaksanaan pembelajaran jarak jauh adalah hal yang perlu diselesaikan secara bersama-sama. Terutama pada "communication technology on learning" Keegan (2008: 4). Ini menjadi hal utama dikarenakan dalam pembelajaran

Vol. 13 No. 2 Juni 2021 


\section{MADRASAH}

Jurnal Pendidikan dan Pembelajaran Dasar

p ISSN: 1979-5599 | e ISSN: 2502-194X

jarak jauh komunikasi merupakan kemampuan yang wajib dimiliki baik guru maupun orang tua supaya materi pembelajaran dapat diterima dan sesuai harapan. Sehingga walaupun dengan menggunakan metode jarak jauh tapi tetap dapat meningkatkan prestasi belajar peserta didik. Pembelajaran di SD Muhammadiyah Pakel telah menggunakan berbagai jenis media komunikasi berbasis teknologi, mulai dari WhatsApp, YouTube, Zoom, Google Classroom dan Googlemeet. Semua media tersebut digunakan untuk mempermudah arus komunikasi antara siswa, guru, dan orang tua dalam pembelajaran. Yusnilita (2020: 6) menyatakan bahwa "the distance learning bring out impact for students achievement." Oleh karena itu penting meningkatkan kemampuan dan keterampilan guru dan orang tua. Essel et al. (2014: 8) menyampaikan bahwa "human knowledge resource development through initial and continuing education is necessary for growth and development and also has far reaching social impact." Pendapat tersebut didukung oleh Prasojo et al. (2017: 4) bahwa "sumber daya manusia dalam pendidikan merupakan aset terpenting dalam proses pembelajaran."

Keterbatasan penelitian ini adalah waktu yang digunakan dalam pengambilan data kurang lama sehingga data yang didapatkan belum seperti yang diharapkan. Kemudian, dalam proses wawancara masih belum mendalami jawaban dari nara sumber dikarenakan proses bertemu untuk wawancara memiliki keterbatasan waktu dikarenakan harus menyesuaikan kondisi. Dampak positif dari adanya kebijakan pembelajaran jarak jauh meminimalisir terjadinya cluster penyebaran virus di sekolah, sehingga siswa dan guru lebih aman. Selain itu, dampak positifnya adalah adanya peningkatan kreativitas guru dalam menyajikan pembelajaran dengan segala keterbatasan yang terjadi. Namun, di samping dampak positif adapula dampak negatif yakni sulitnya membiasakan, mengawasi, dan mengembangkan pendidikan karakter. Hal ini terindikasi dari berkurangnya kedisiplinan siswa dalam belajar, misalnya tidak tepat waktu dalam mengerjakan dan mengumpulkan tugas.

\section{KESIMPULAN}

Berdasarkan hasil analisis dan pembahasan di atas maka dapat disimpulkan bahwa terdapat tiga faktor utama yang perlu diperhatikan dalam implementasi pembelajaran jarak jauh yaitu kebijakan, keaktifan SDM, dan proses pembelajaran. Pandemi Covid-19 telah mentransformasi sebagian besar kehidupan di dunia, termasuk dalam dunia pendidikan. Selama ini, manusia cenderung belajar di sekolah. Selama itu pula, orang tua cenderung pasrah pada pendidikan yang ada di sekolah. Dengan terjadinya pandemi ini, berlakunya pembelajaran jarak jauh menyebabkan perubahan dan penyesuaian dalam proses pendidikan. Tentu, dibutuhkan kolaborasi yang baik dari tripusat pendidikan. Penelitian ini direkomendasikan bagi guru dan orang tua. Guru yang ada di sekolah dengan memberikan proses pembelajaran tidak hanya sekadar memberikan materi saja melainkan juga memberikan arahan dan sikap untuk pengembangan karakter pada siswa sehingga siswa tidak hanya memiliki nilai yang tinggi juga memiliki sikap yang baik selama proses pembelajaran yang dilakukan dengan jarak jauh. Rekomendasi untuk orang tua adalah kewajiban orang tua dalam membersamai dan mendampingi anak dalam proses pembelajaran dan menyelesaikan tugas yang diberikan oleh guru. Sehingga anak mampu menyelesaikannya dengan baik

Vol. 13 No. 2 Juni 2021 
dikarenakan perhatian orang tua. Implikasi dari hasil penelitian ini adalah mampu meningkatkan hasil belajar siswa, mampu mengembangkan sikap karakter yang baik bagi siswa. Implikasi secara praktis adalah mampu mengembangkan sikap pada orang tua untuk parent involvement kepada para anak dalam belajar di rumah. Implikasi praktis untuk guru adalah mampu meningkatkan dan mengembangkan diri dalam proses pembelajaran khususnya melalui inovasi belajar.

\section{REFERENSI}

Abidah A, Hidaayatullah HN, Simamora R, Fehabutar D, Mutakinati L. 2020. The Impact of Covid-19 to Indonesian Education and Its Relation to the The Impact of Covid-19 to Indonesian Education and Its Relation to the Philosophy of " Merdeka Belajar ." Stud Philos Educ. 1(1):38-49.

Abuhammad S. 2020. Heliyon Barriers to distance learning during the COVID-19 outbreak: A qualitative review from parents' perspective. Heliyon [Internet]. 6(November):e05482. https:// doi.org/10.1016/j.heliyon.2020.e05482

Akther U. 2016. Psychological Impact of Distance Education Technologies in Student $\hat{a} €^{\mathrm{TM}} \mathrm{s}$ Personal Development . PSYCHOLOGICAL IMPACT OF DISTANCE EDUCATION. Int J Dev Educ Psychol. 1(2):203-211.

Amir LR, Tanti I, Maharani DA, Wimardhani YS, Julia V, Sulijaya B. 2020. Student perspective of classroom and distance learning during COVID-19 pandemic in the undergraduate dental study program Universitas Indonesia. Int J Multikultural Multireligious Underst. 7(6):1-8.

Apriyanti C. 2020. The parents role in guiding distance learning and the obstacle during covid-19 outbreak. J Ilm Pendidik Dasar. VII(2):68-83.

BPS-Statistics Indonesia. 2019. Telecommunication statistics in Indonesia. Sari E, Utoyo S, Anggraini L, editors. [place unknown]: BPS-Statistics Indonesia, Jakarta, Indonesia.

Churiyah M, Sholikhan, Filianti, Sakdiyyah DA. 2020. International Journal of Multicultural and Multireligious Understanding Indonesia Education Readiness Conducting Distance Learning in Covid-19 Pandemic Situation. Int J Multicult Multireligious Underst. 7(6):491-507.

Darmawan D. 2009. Peningkatan Aksesibilitas “ 3 M-Mobile Learning ” sebagai Layanan Pendidikan. MIMBAR. 30(1):28-41.

Denzin NK, Lincoln YS. 2018. The sage handbook of qualitative research fifth edition. United States: SAGE Publications, Inc.

Essel R, Boateng-Owusu W, Saah AA. 2014. Effect of sistance learner-perception of course materials on access to learning for professional development: a case study of centre for continuing education, university of cape coast, ghana. Cent fo Distance Contin Educ. 3(3):1-5.

Keegan D. 2008. The impact of technologies on distance learning students. Francesco Agrusti.

Kristanto YD. 2020. Pembelajaran Jarak Jauh. Lise Creat Commons Atribusi 40 Int.:1-12. Mahmudah FN, Cahya E. 2020. What makes employees productive and have high performance? human capital investment in universities. Asian J Educ Soc Stud [Internet]. 11(1):21-36. https:/ / doi.org/10.9734/ajess/2020/v11i130281

Vol. 13 No. 2 Juni 2021 


\section{MADRASAH}

Jurnal Pendidikan dan Pembelajaran Dasar

p ISSN: 1979-5599 | e ISSN: 2502-194X

P a g e | $\mathbf{1 2 5}$

Mesiono. 2010. Kebijakan pendidikan dan pengembangan sekolah (school development). J Tazkirah. 2(2):1-16.

Ngyen AV. 2017. The Impact of Online Learning Activities on Student Learning Outcome in Blended Learning. J Inf Knowledgement. 1(9):1-40.

Pemerintah Indonesia. 2020. Keputusan menteri pendidikan dan kebudayaan republik indoneisa nomor 719/P/2020 tentang pedoman pelaksanaan kurikulum pada satuan pendidikan dalam kondisi khusus. Jakarta: Sekretariat Negara.

Prasojo LD, Mukminin A, Mahmudah FN. 2017. Manajemen strategi human capital dalam pendidikan. Yogyakarta: UNY Press.

Rahmawati SD. 2009. Kendala pelaksanaan pembelajaran jarak jauh melalui internet pada mahasiswa PJJ S1 PGSD universitas negeri semarang. [place unknown].

Ramdhani A, Ramdhani MA. 2017. Konsep umum pelaksanaan kebijakan publik. J Publik [Internet]. 11(1):1-12. 2 www.jurnal.uniga.ac.id

Rizaldi DR, Fatimah Z. 2020. How the distance learning can be a solution during the Covid-19 pandemic. Int J Asian Educ. 1(3):117-124.

Sahlberg P. 2020. Will the pandemic change schools? J Prof Cap Community. 5(3-4):359365.

Sari W, Rifki AM, Karmila M. 2020. Pembelajaran Jarak Jauh Pada Masa Darurat Covid 19. J MAPPESONA.(1):12.

Stake RE. 2010. Qualitative research studying how thins work. New York: A Division of Guilford Publications, Inc.

Suyahman. 2016. Analisis kebijakan pendidikan gratis di sekolah menengah atas dalam kaitannya dengan kualitas pendidikan menengah atas. J Pendidik Kewarganegaraan. 6(2):1047-1054.

Suyantiningsih. 2003. Sistem pendidikan jarak jauh interaktif: urgensi teknologi informasi dalam pendidikan jarak jauh (distance education). Din Pendidik. 10(1):112.

Syakdiyah A, Mahmudah NF, Wijayanti W. 2019. Active Learner Strategies in Era of Disruption : a Literature Review. Proc First Int Conf Progress Civ Soc. 317(1):165168.

Yusnilita N. 2020. The impact of online learning: student's views. ETERNAL (English Teach Journal). 11(1):57-61.

Vol. 13 No. 2 Juni 2021 